\title{
The English Prefixes Analysis with Reference to Agricultural Development in a Frontier Region of Java: Besuki, 1870 - Early 1990s
}

\author{
Ni Luh Radnyani ${ }^{\text {* }}$ \\ English Department, Faculty of Arts, Udayana University \\ [ni_luhradnyani@ymail.com]
}

\begin{abstract}
Prefix is a bound morpheme which is added to the initial of the base word. This study is concerned with the types, meanings and functions of the English Prefixes found in a scientific book entitled "Agricultural Development in a Frontier Region of Java: Besuki, 1870 - Early 1990s" by Nawiyanto. This study applied two theories in order to analyze the data. The first is the theory of type and meaning of the English prefixes proposed by Quirk (1973). The second is the theory of functions of the English prefixes proposed by Bauer (1983). The data of this study were taken directly from the scientific book itself. The data were collected using the contentanalysis method and note-taking technique. The collected data were analyzed using the descriptive and qualitative method. Then, all of the analyses were presented using both formal and informal methods. The analyses show that almost all types of the English prefixes found in the book. However, most of them belong to the class-maintaining English prefixes and the attachment of those prefixes give a new meaning to the base words after its attachment.
\end{abstract}

Keywords: morphology, prefixes, scientific book

\begin{abstract}
Abstrak
Kata imbuhan berupa awalan biasanya terletak di depan sebuah kata dasar. Penelitian ini berfokus untuk menganalisis tipe, makna, dan fungsi dari kata imbuhan berupa awalan yang ada dalam bahasa Inggris. Awalan tersebut di cari dalam sebuah buku ilmiah yang berjudul "Agricultural Development in a Frontier Region of Java: Besuki, 1870 - Early 1990s" yang di karang oleh Nawiyanto. Penelitian ini menggunakan dua buah teori. Teori yang pertama adalah teori tipe dan makna dari kata imbuhan berupa awalan dalam bahasa Inggris yang dikemukakan oleh Quirk dan teori yang kedua adalah teori fungsi dari kata imbuhan berupa awalan dalam bahasa Inggris oleh Bauer. Data dalam penelitian ini data diambil langsung dari teks yang terdapat dalam buku ilmiah tersebut. Data tersebut dikumpulkan melalui metode analisis-konten dan teknik mencatat. Data yang terkumpul di analisis menggunakan metode deskriptif dan kualitatif. Seluruh data yang telah di analisis ditampilkan melalui metode formal dan informal. Hasil analisis menunjukkan bahwa hampir seluruh tipe dari kata imbuhan berupa awalan dalam bahasa Inggris dapat ditemukan dalam buku tersebut. Sebagian besar kata dasar yang mengandung kata imbuhan tegolong ke dalam kelas kata yang tetap dan hampir seluruh maknanya berubah setelah mendapat kata imbuhan berupa awalan.
\end{abstract}

Kata kunci: morfologi, kata imbuhan, buku ilmiah

\section{Background of the Study}

Morphology is a branch of linguistics which studies how words are structured and how they are put together from smaller parts. Morphology is also called the study of morphemes and their different forms (allomorphs) and the way they combine in word formation. The word-formation process or the 
morphological process is the process of forming new words with the rules of morphology.

In morphology, there are so many word-formation processes and one of them is affixation. Affixation is the adding of bound morphemes to the base to form a word. Affixation consists of prefixes, suffixes, and infixes. The bound morphemes added initially to the base are called prefixes, those inserted into the base are called infixes, and those added to the end of the base are called suffixes. However, this research focuses only on the English prefixes. Based on a general theory proposed by Quirk (1973: 431) prefixes do not generally alter the wordclass of the base. Productive prefixes normally have a light stress on their first syllable. He also stated that there are some types of prefixes in English. They included negative prefixes, reversative or privative prefixes, pejorative prefixes, prefixes of degree or size, prefixes of attitude, locative prefixes, prefixes of time and order, number prefixes, other prefixes and conversion prefixes.

In order to make the study becomes more specific, it is necessary to use a certain reference. Thus, a scientific book entitled "Agricultural Development in a Frontier Region of Java: Besuki, 1870 Early 1990s" becomes the object of this study. A scientific book is a work of nonfiction, usually written by a scientist, researcher, or professor. That book is chosen because it contains so many types of the English prefixes so that it can support this analysis to be more complete.

There are many previous studies that have analyzed the affixation in English. However, most of them only described specifically about the English suffixes. Therefore, this current research is different than others because it is concerned with the types, meanings and functions of the English prefixes found in a scientific book. The two main theories proposed by Quirk (1973) and Bauer (1983) were applied to make this analysis becomes more accurate.

\section{Problems of the Study}

a) What types of English prefixes found in a scientific book entitled "Agricultural Development in a Frontier Region of Java: Besuki, 1870 - Early 1990s"?

b) What are the meanings and functions of those prefixes?

\section{Aims of the Study}

a) To find out the types of English prefixes in the scientific book.

b) To identify the meanings and functions of those English prefixes.

\section{Research method}

The research method of this study includes the data source, method and technique of collecting data, method and technique of analyzing data and method and technique of presenting data. Each part of research method is explained as follows:

\subsection{Data source}

The data used in this discussion were obtained from a scientific book. A scientific book is a work of nonfiction, usually written by a scientist, researcher, or professor. The book entitled "Agricultural Development in a Frontier Region of Java: Besuki, 1870 - Early 1990s". It is written by Nawiyanto. It was published on June 2013 by Galang Press, Yogyakarta. The data were chosen because it contains so many types of the English prefixes which could support this analysis to be more detailed.

\subsection{Method and technique of collecting data}

The method used in this study was content-analysis. According to Kothari 
(2004: 110), content-analysis consists of analyzing the contents of documentary materials such as books, magazines, newspapers and the contents of all other verbal materials which can be either spoken or printed. The technique used in order to collect the data was note-taking. Note-taking is the practice of writing down key points of information in a systematic way. Moreover, there were some steps to be done in order to collect the data perfectly. It was conducted by reading the scientific book comprehensively. Then, the next step was by highlighting some words which contain English prefixes. After that, grouping the English prefixes into some types.

\subsection{Method and technique of analyzing data}

The data of this study were analyzed using the descriptive and qualitative method. It means that the data were analyzed using a deep explanation or description without involving measurement or statistics. Moreover, the data of this study were described in detail based on the relevant theories to the topic of discussion. All the data found in the scientific book entitled "Agricultural Development in a Frontier Region of Java: Besuki, 1870 - Early 1990s" were processed through some steps. First, the collected data were classified into some types and meanings of the English prefixes using a theory proposed by Quirk (1973: 431). Then, to identify the functions of the prefixes in English, the theory proposed by Bauer (1983: 217) was applied.

\subsection{Method and technique of presenting analysis}

The data were presented and described in sentences through several steps. First, the collected data were classified into several types of the English prefixes. Next, all types of the
English prefixes found in the scientific book were described in the form of paragraph in order to analyze the meanings and functions of those English prefixes. The last step was the classification of its types, meanings and functions were presented in the form of tables. Moreover, this research applied both informal and formal methods in order to present the analysis. Informal method means that this study was explained by giving some deeper description using words. On the other hand, formal method means that this study was being presented using a form of table.

\section{Results and discussions}

Prefixes consist of ten types namely negative prefixes, reversative prefixes, pejorative prefixes, prefixes of degree or size, prefixes of time and order, prefixes of attitude, locative prefixes, number prefixes, other prefixes, and conversion prefixes. Every prefix has their own meanings. The functions of the English prefixes were divided into two parts. There were class-changing and classmaintaining prefixes. The analyses of English prefixes are explained as follows.

\subsection{Negative Prefixes}

Negative prefixes are attached to the base word and have a function to form a new negative word.

Data 1

For a long time the region was relatively unstable due to the warfare between the Javanese kingdoms of Majapahit, Demak, and later also Mataram and the Blambangan supported by Balinese kingdoms. (Agricultural Development in a Frontier Region of Java: Besuki, 1870 Early 1990s: 07)

The underlined word above contains a negative prefix. The word 'unstable' in the sentence above is derived from the base word 'stable'. The base form 
attached by a negative prefix unbecomes 'unstable'. Un- means 'the opposite of or not'. It is usually added to the adjective word class adjective and participles. The base word 'stable' belongs to adjective. Even after it is attached by a negative prefix un- and becomes 'unstable', it remains an adjective. The new lexeme 'unstable' can be determined as an adjective because of its function in the sentence is modifying the noun "region". The attachment of the negative prefix un- does not change the word class of the base. It maintains the adjective word class. Thus, it belongs to class-maintaining prefixes. However, it has changed the meaning of the base word. 'Stable' means "being resistant to change of condition or situation". Then, the negative prefix un- changes the meaning into "not stable".

Table 1. New Lexeme in Negative Prefixes

\begin{tabular}{ccccc}
\hline Base & Prefix & Process & Meaning & Function \\
\hline Stable & Un- & Un- + & Not & Maintaini \\
& & stable $=$ & stable & ng the \\
& & Unstabl & & word \\
& & e & & class \\
& & & & adjective \\
\hline
\end{tabular}

\subsection{Reversative Prefixes}

Reversative or Privative Prefixes describe actions being reversed or of antonymic character.

Data 2

In short, the depopulation of the Besuki region was primarily caused by political factors. (Agricultural Development in a Frontier Region of Java: Besuki, 1870 Early 1990s: 25)

The word 'depopulation' in the sentence above is derived from the base word 'population'. The base form is attached by the reversative prefix debecomes 'depopulation'. De- means 'reversing the action'. It is generally combined with the verb word class and abstract nouns. The base word 'population' is an abstract noun. Even after it is attached by the reversative prefix de- and becomes 'depopulation', it remains a noun. The new lexeme 'depopulation' can be determined as a noun because of its function in the sentence modifies the phrase "Besuki region". The attachment of the reversative prefix de- does not change the word class of the base. It maintains the word class verb. Thus, it belongs to classmaintaining prefixes. However, it has changed the meaning of the base word. 'Population' means "all the inhabitants of a particular place". Then, the reversative prefix de- becomes deform modifies the meaning into "to reverse action of population".

Table 2. New Lexeme in Reversative Prefixes

\begin{tabular}{|c|c|c|c|c|}
\hline Base & Prefix & Process & Meaning & Function \\
\hline $\begin{array}{c}\text { Popula } \\
\text { tion }\end{array}$ & De- & $\begin{array}{c}\text { De- }+ \\
\text { populat } \\
\text { ion }= \\
\text { Depop } \\
\text { ulation }\end{array}$ & $\begin{array}{l}\text { Reverse } \\
\text { action of } \\
\text { populati } \\
\text { on }\end{array}$ & $\begin{array}{l}\text { Maintaini } \\
\text { ng the } \\
\text { word } \\
\text { class noun }\end{array}$ \\
\hline
\end{tabular}

\subsection{Pejorative Prefixes}

The function of pejorative prefixes is to show something in negative sense.

Data 3

Conflict was more often associated with extortion, maltreatment, and land ownership issues, and was sometimes mixed with religious issues. (Agricultural Development in a Frontier Region of Java: Besuki, 1870 - Early 1990s: 43)

The word 'maltreatment' in the sentence above is derived from the base 'treatment'. The base form is attached by a pejorative prefix mal- becoming 'maltreatment'. Mal- means 'bad' or 'badly'. It is generally attached to the verb word class, adjective word class, participles and abstract nouns. The base word 'treatment' is a noun. Even after it is attached by the pejorative prefix malbecoming 'maltreatment', it remains a noun. The new lexeme 'maltreatment' can be seen as a noun because of its function in the sentence modifies the subject "conflict". The attachment of the 
pejorative prefix mal- does not change the word class of the base. It maintains a noun. Thus, it belongs to classmaintaining prefixes. However, it shifts the meaning of the base word. 'Treatment' means "the process of treating something or someone". Then, the pejorative prefix mal- forms 'maltreatment' which modifies the meaning into "the bad treatment".

Table 3. New Lexeme in Reversative Prefixes

\begin{tabular}{ccccc}
\hline Base & Prefix & Process & Meaning & Function \\
\hline Treat & Mal- & Mal- & Bad & Maintaini \\
ment & & treatme & treatmen & ng the \\
& & $\mathrm{nt}=$ & $\mathrm{t}$ & word class \\
& & Maltrea & & noun \\
& & tment & & \\
\hline
\end{tabular}

\subsection{Prefixes of Degree or Size}

These prefixes can be used to measure something.

Data 4

This is followed by a discussion of transport problem facing the region and measures taken to overcome these after the 1930s both in terms of infrastructure facilities and means of transport. (Agricultural Development in a Frontier Region of Java: Besuki, 1870 - Early 1990s: 48)

The word 'overcome' in the sentence above is derived from the base 'come'. The base form is attached by a prefix of degree over- becoming 'overcome'. Over- means 'too much'. It is commonly added to the verb word class, participles and adjectives. The base word 'come' belongs to verb. Even after it is attached by the prefix of degree over- to form 'overcome', it remains a verb. The new lexeme 'overcome' can be seen as an adjective because its function in the sentence is modifying the subject "region and measures taken". The addition of the prefix of degree over- does not change the word class of the base. It maintains the word class verb. Thus, it belongs to the class-maintaining prefixes. However, it has changed the meaning of the base word. 'Come' means "to approach to a particular person or something". Then, the prefix of degree over- forming 'overcome' shifts the meaning to "too much come".

Table 4. New Lexeme in Prefixes of Degree or Size

\begin{tabular}{ccccc}
\hline Base & Prefix & Process & Meaning & Function \\
\hline Come & Over- & Over- + & Too & Maintain \\
& & come $=$ & much & ing the \\
& & Overco & come & word \\
& me & & class \\
& & & & verb \\
\hline
\end{tabular}

\subsection{Prefixes of Attitude}

These prefixes show the attitude and manner of human beings.

\section{Data 5}

This view assumed that farmers were basically anti-market and tended to idealise traditional society depicted as a harmonious world without conflict. (Agricultural Development in a Frontier Region of Java: Besuki, 1870 - Early 1990s: 10)

The word 'anti-market' in the sentence is derived from the base market. The base form is added the prefix of attitude anti- to make 'anti-market'. Antimeans 'against'. It is generally combined with the noun word class, denominal adjectives, and adverbs. The base word market is an adjective. Even after it is attached by a prefix of attitude anti- to make 'anti-market', it is still an adjective. The new lexeme 'anti-market' can be determined as an adjective because its function in the sentence modifies the subject "farmers". The addition of the prefix of attitude anti- does not change the word class of the base. It maintains the adjective word class. Thus, it belongs to class-maintaining prefixes. However, it changes the meaning of the base word. Market means "relating to a place of selling and buying something". Then, the prefix of attitude anti- forms 'anti- 
market', shifting the meaning to "against the market".

Table 5. New Lexeme in Prefixes of Attitude

\begin{tabular}{ccccc}
\hline Base & Prefix & Process & Meaning & Function \\
\hline Mark & Anti- & Anti- + & Against & Maintain \\
et & & market & market & ing the \\
& & Anti- & & word \\
& & market & & class \\
& & & & adjective \\
\hline
\end{tabular}

\subsection{Locative Prefixes}

Locative prefixes determine the place or relative place or direction of actions or objects.

Data 6

Unlike the Madurese, the Using people were regarded as sub-ethnic Javanese. (Agricultural Development in a Frontier Region of Java: Besuki, 1870 - Early 1990s: 42)

The word 'sub-ethnic' in the sentence above is derived from the base 'ethnic'. The base form is attached by the locative prefix sub- to make 'sub-ethnic'. Submeans 'beneath' or 'lesser in rank'. It is commonly added to the noun word class, adjective word class and verb word class. The base word 'ethnic' is an adjective. Even after it is attached by the locative prefix sub- and becomes 'sub-ethnic', it remains an adjective. The new lexeme 'sub-ethnic' can be determined as an adjective because of its function in the sentence modifies the noun "Javanese". The attachment of the locative prefix sub- does not change the word class of the base. It maintains the adjective word class. Thus, it belongs to classmaintaining prefixes. However, it changes the meaning of the base word. 'Ethnic' means "relating to a group of people having a common national or cultural tradition". Then, the locative prefix sub- becomes 'sub-ethnic', shifting the meaning to "beneath the ethnic".
Table 6. New Lexeme in Locative Prefixes

\begin{tabular}{ccccc}
\hline Base & Prefix & Process & Meaning & Function \\
\hline Ethnic & Sub- & $\begin{array}{c}\text { Sub- } \\
\text { ethnic }\end{array}$ & $\begin{array}{c}\text { Beneath } \\
\text { of ethnic }\end{array}$ & $\begin{array}{c}\text { Maintaini } \\
\text { ng the } \\
\end{array}$ \\
& & Sub- & & word \\
& ethnic & & class \\
& & & & adjective \\
\hline
\end{tabular}

\subsection{Prefixes of Time and Order}

The prefixes of time and order determine the time when the event happens.

Data 7

Governor General Raffles repurchased the areas in 1814, after they were sold to Han Tjan Pit during the Daendels' administration.

(Agricultural Development in a Frontier Region of Java: Besuki, 1870 - Early 1990s: 27)

The word 'repurchased' in the sentence above is derived from the base 'purchased'. The base form is attached by the prefix of time re- to make 'repurchased'. Re- means 'again' or 'back'. It is commonly added to the word verb class and abstract nouns. The base word 'purchased' is a verb. Even after it is combined with the prefix of time re- it becomes 'repurchased'; it remains a verb. The new lexeme 'repurchased' can be determined as a verb because of its function in the sentence modifies the noun "areas". The attachment of the prefix of time re- does not change the word class of the base. It maintains the word class verb. Thus, it belongs to classmaintaining prefixes. However, it changes the meaning of the base word. 'Purchased' means "to be bought". Then, the prefix of time re- becomes 'repurchased', shifting the meaning to "to be purchased again".

Table 7. New Lexeme in Prefixes of Time and Order

\begin{tabular}{ccccc}
\hline Base & Prefix & Process & Meaning & Function \\
\hline Purch & Re- & Re- + & Purchase & Maintain \\
ased & & purchas & d again & ing the \\
& & ed $=$ & & word \\
& & Repurch & & class \\
& & ased & & adjective \\
\hline
\end{tabular}




\subsection{Number Prefixes}

These prefixes determine the amount, quantity, or scope of something.

Data 8

In smaller acreages, soybean cultivation on tegalan (dry lands) is also found, particularly in Bondowoso where soybean is grown either as a monocrop planted from February to April or an intercrop planted in combination with other palawija such as maize and cassava between October and November. (Agricultural Development in a Frontier Region of Java: Besuki, 1870 - Early 1990s: 117).

The word 'monocrop' is derived from the base 'crop'. The base form is attached by the number prefix mono- to make 'monocrop'. Mono- means 'one'. It is commonly added to the noun word class and adjective word class. The base word 'crop' is a noun. Even after it is attached by the number prefix mono- to make 'monocrop', it is still a noun. The new lexeme 'monocrop' can be seen as a noun because of its function in the sentence is modifying the adjective "planted". The attachment of the number prefix monodoes not change the word class of the base. It maintains the noun word class. Thus, it belongs to class-maintaining prefixes. However, it has changed the meaning of the base word. 'Crop' means "a cultivated plant". Then, the number prefix mono- becomes 'monocrop', changing the meaning into "one crop".

Table 8. New lexeme in Number Prefixes

\begin{tabular}{ccccc}
\hline Base & Prefix & Process & Meaning & Function \\
\hline Crop & Mono- & Mono- + & One crop & Maintain \\
& & crop= & & ing the \\
& & Monocro & & word \\
& & class \\
& & & & noun \\
\hline
\end{tabular}

\subsection{Conversion Prefixes}

The conversion prefixes have the primary effect to change the class or type of words or to convert.

Data 9
The best way to broaden the tax base was therefore to encourage new settlers to open up new land. (Agricultural Development in a Frontier Region of Java: Besuki, 1870 - Early 1990s: 142)

The underlined word 'encourage' is derived from the base 'courage'. The base form is attached by the conversion prefix en- to form 'encourage'. Enmeans 'to make' if it is added to adjectives and 'to put into' if it is combined with a noun. It is commonly added to the noun word class and adjective word class. The base word 'courage' is a noun. After it is attached by the conversion prefix en- to form 'encourage', it changes into a verb. The new lexeme 'encourage' can be determined as a verb because of its function in the sentence modifies the phrase "new settlers". The attachment of the conversion prefix en- has changed the word class of the base. Thus, it belongs to class-changing prefixes. It also shifts the meaning of the base word. 'Courage' means "strength in the face of pain or grief". Then, the conversion prefix enbecomes 'encourage', changing the meaning into "to put into "courage".

Table 9. New Lexeme Conversion Prefixes

\begin{tabular}{ccccc}
\hline Base & Prefix & Process & Meaning & Function \\
\hline Courage & En- & En- + & To put & Changing \\
& & courage & courage & $\begin{array}{c}\text { the word } \\
\text { class from } \\
\end{array}$ \\
& & & noun to \\
& Encoura & & verb \\
\hline
\end{tabular}

\section{Conclusions}

Based on the data analyzed, it can be concluded that almost all types of the English prefixes can be found from the scientific book. Those prefixes include negative prefixes, reversative or privative prefixes, pejorative prefixes, prefixes of degree or size, prefixes of attitude, locative prefixes, prefixes of time and order, number prefixes, and conversion prefixes. There was only one type of the 
English prefixes which could not be found namely other prefixes.

The total data analyzed is thirty five words. About thirty four words contained English prefixes which belonged to the class maintaining and only one word found as class-changing. Most types of the English prefixes found were attached to noun, adjective, participle, and verb bases. The whole of the adjective, participle, verb and even noun words change into their meanings because of the English prefix attachment. However, not all types of the English prefixes change the grammatical class of the base word after their attachment.

\section{References}

Bauer, L. (1983). English WordFormation. Cambridge University Press, UK.

Kothari, C. R. (2004). Research Methodology. New Age International (P) Ltd, Publishers. New Delhi.

Nawiyanto, S. (2003). Agricultural Development in a Frontier Region of Java: Besuki, 1870 - Early 1990s. Galang Press, Yogyakarta.

Quirk, R. (1973). A University Grammar of English. Longman, New York.

\footnotetext{
Words' Definition, Resource:

http://www.dictionary.com/

[Accessed 18 October 2017].
} 